\title{
Southern Midwest States
}

National Cancer Institute

\section{Source}

National Cancer Institute. Southern Midwest States. NCI Thesaurus. Code C43452.

The area in the United States comprised of the following states: Arkansas, Louisiana, Oklahoma and Texas. 